\title{
COURSE OUTCOMES ATTAINMENT FOR DATA STRUCTURE COURSE USING DIRECT AND INDIRCT METHODS
}

\author{
Ms. Varsha T. Lokare ${ }^{1}$, Mr. Prakash M. Jadhav ${ }^{2}$ \\ ${ }^{1}$ Information Technology, Rajarambapu Institute of Technology, Sakharale \\ ${ }^{2}$ Mechanical, Institute, Rajarambapu Institute of Technology, Sakharale \\ 1 varsha.lokare@ritindia.edu \\ ${ }^{2}$ prakash.jadhav@ritindia.edu
}

\begin{abstract}
The term Course Outcomes (COs) plays a vital role in Outcome-Based Education (OBE). The attainment of Program Educational Objective (PEOs) and Program Outcomes (POs) is depends on the attainment of Course Outcomes (COs). In this paper, we have measured the $\mathrm{CO}$ attainment for Data Structure course on the basis of two methods; one is direct method in which students' marks have been considered as an input data. While another method, indirectly measures the $\mathrm{CO}$ attainment by taking feedback from Course Exit Survey. A suitable weight-age is given to direct and indirect method i.e. $80 \%$ and $20 \%$ respectively. The course Data Structure is chosen for this study of $\mathrm{CO}$ attainment because this course is very important for students' employment i.e. placement as well as competitive exams. The attempt is made here to find out accurate attainment of COs so that corrective actions can be taken for the next batch to improve the teaching learning process and intern higher attainment of COs and intern PEOs. Finally the analysis of results obtained by both direct and indirect methods is also shown in this paper.
\end{abstract}

Keywords: Outcome-Based Education (OBE), Program Educational Objective (PEOs), Program Outcomes (POs), Course Outcomes (COs).

\footnotetext{
Ms. Varsha T. Lokare ${ }^{1}$

${ }^{1}$ Information Technology, Rajarambapu Institute of Technology, Sakharale
}

\section{INTRODUCTION}

In India Engineering education system already adopted Outcome based Education (OBE), from last few years along with home accreditation body, National Board of Accreditation (NBA) [1]. In OBE, individual course outcomes need to be attained up to some minimum level [2]. In OBE, individual course outcomes need to be attained up to a desired level. The level may vary with different courses but at least $50 \%$ attainment is mandatory for all courses. In our Rajarambapu Institute of Technology (RIT), we have extended that range up to $75 \%$. In this paper we have given detail explanation for evaluation of $\mathrm{CO}$ attainment. Here we select data structure course which is for Second Year B. Tech. students of Information Technology branch at our institute. The reason behind selection of this course is not only to focus on core courses but also this subject is equally important for students' employment i.e. placement as well as competitive exams like GATE. The next section explains $\mathrm{CO}$ attainment measurement methods both direct and indirect in details, and subsequent sections give the analysis of $\mathrm{CO}$ attainment methods along with overall $\mathrm{CO}$ attainment by both methods.

\section{CO-ATTAINMENT Measurement Methods}

There are various methods available to measure the attainment of COs. There are total five course outcomes are specified for data structure course i.e. it is expected that after completing this course successfully, students must be able to demonstrate these things.

1. Discuss strengths, primitive operations and applications of Data structures.

2. Implement various data structures using $\mathrm{C}$ language

3. Describe various terminologies and traversal techniques related to tree and graph 
4. Demonstrate the use of various hash functions with example. 5. Choose appropriate data structure while building application. Generally, the approach in evaluating the attainment of $\mathrm{CO}$ is using existing data from students' marks, for example from the test results, final exam, quizzes and lab report [3]. These assessments are referred as formal assessment. Here we have considered two methods one is direct and another is indirect to measure the attainment of data structure course in academic year 2014-15. The brief explanation of each method along with sample evaluation is given below.

\section{A] Direct Method}

In our RIT institute, the assessment methods are divided into 3 categories: (1) End Semester Examination (ESE) (2) Mid Semester Examination (MSE) (3) In Semester Examination (ISE). Highest weight-age (i.e. 50\%) is given to ESE and $30 \%$ weight age is given for MSE. ISE (20\% weight-age) is again divided into 2 sub tasks one is Objective Test and another is Debugging Test in which $10 \%$ weight age is given for each sub task respectively. The data used for evaluating $\mathrm{CO}$ attainment is obtained from the students' mark from these assessments.

In this paper we calculate Co attainment of data structure course for academic year 2014-15. Following Procedure has been applied to calculate score of each $\mathrm{CO}$ :

Algorithm1: CO Attainment Measurement through direct approach

Input: 1) Marks of all students in ESE, MSE, ISE

2) Mapping of Question Paper to $\mathrm{CO}$

Output: Score of each CO in \%

To explain the total evaluation procedure, here we consider one sample input i.e. marks of 10 students in MSE examination (Table 1) along with MSE question paper mapping with Cos (Table 2).

Table1: Sample Marks of 10 students

\begin{tabular}{|c|c|c|c|c|c|c|c|c|c|}
\hline \multirow{3}{*}{$\begin{array}{l}\text { Roll } \\
\text { No. }\end{array}$} & \multicolumn{9}{|c|}{ Marks } \\
\hline & \multicolumn{3}{|c|}{ Q.1 } & \multicolumn{3}{|c|}{ Q.2 } & \multicolumn{3}{|c|}{ Q.3 } \\
\hline & $\mathbf{A}$ & B & $\mathbf{C}$ & $\mathbf{A}$ & B & $\mathbf{C}$ & $\mathbf{A}$ & B & $\mathbf{C}$ \\
\hline $\mathrm{R} 1$ & 8 & 4 & 7 & & 4 & 4 & 4 & 6 & 7 \\
\hline $\mathrm{R} 2$ & 8 & & 8 & & 8 & 5 & 6 & 6 & 9 \\
\hline R3 & 2 & & 6 & 3 & 5 & 4 & 6 & 7 & 7 \\
\hline R4 & & 2 & 2 & & 2 & 5 & 9 & 6 & 3 \\
\hline R5 & 3 & & 8 & 6 & 8 & 7 & 9 & 6 & 8 \\
\hline R6 & 3 & & 6 & & 2 & 4 & 9 & 6 & \\
\hline R7 & 8 & & 8 & 3 & 5 & 3 & 3 & 7 & 4 \\
\hline R8 & 2 & & 8 & 2 & 8 & 5 & 6 & 6 & \\
\hline R9 & 8 & & 8 & 4 & 3 & 7 & 9 & 6 & 9 \\
\hline R10 & 2 & 4 & 7 & 0 & 8 & 6 & 6 & 6 & 7 \\
\hline $\begin{array}{l}\text { Total } \\
\text { Mark }\end{array}$ & 44 & 10 & 68 & 18 & 53 & 50 & 67 & 62 & 54 \\
\hline $\begin{array}{l}\text { Avg } \\
\text { Mark }\end{array}$ & $\begin{array}{c}4.8 \\
8\end{array}$ & $\begin{array}{c}3.3 \\
3\end{array}$ & 6.8 & 3 & 5.3 & 5 & 6.7 & 6.2 & $\begin{array}{c}6.7 \\
5\end{array}$ \\
\hline
\end{tabular}

Table2: MSE Question Paper (2014-15) to CO Mapping

\begin{tabular}{|l|l|l|l|l|l|l|l|l|l|}
\hline \multirow{2}{*}{ CO } & \multicolumn{10}{c|}{ Questions } \\
\hline & \multicolumn{3}{|c|}{ Q.1 } & \multicolumn{3}{c|}{ Q.2 } & \multicolumn{3}{|c|}{ Q.3 } \\
\hline & A & B & C & A & B & C & A & B & C \\
& & & & & & & & & \\
\hline CO1 & $\checkmark$ & & & & $\checkmark$ & & & $\checkmark$ & \\
\hline CO2 & & $\checkmark$ & & $\checkmark$ & & & $\checkmark$ & & \\
\hline CO3 & & & $\checkmark$ & & & & & & \\
\hline CO4 & & & & & & $\checkmark$ & & & \\
\hline CO5 & & & & & & & & & $\checkmark$ \\
\hline
\end{tabular}

Step 1: Calculate average marks (AvgM ) associated with each Course outcome $\left(\mathrm{CO}_{\mathrm{i}}\right)$.

(a) Measure no of questions $\left(\mathrm{Que}_{\mathrm{i}}\right)$ mapped with respective $\mathrm{CO}_{\mathrm{i}}$

(b) Perform summation of average marks obtained by students in respective questions.

Below is one sample calculation for $\mathrm{CO} 1$ by refereeing Table no.1 as total 3 questions are mapped with CO1 i.e. Q.1(a), Q.2(b) and Q.3(b)

$$
\begin{aligned}
\text { AvgM } & =\text { AvgMQ.1(a) +AvgMQ.2(b) +AvgMQ.3(b) } \\
& =4.88+5.3+6.2 \\
& =16.38
\end{aligned}
$$

Step 2: Calculate summation of Total Marks $(\text { TotalM })_{i}$ in step 1 questions associated with respective $\mathrm{CO}_{\mathrm{i}}$

Here we assume each question carries 10 marks, hence TotalM for $\mathrm{CO} 1=30$

Step3: CO attainment can be measured by applying following formulae:

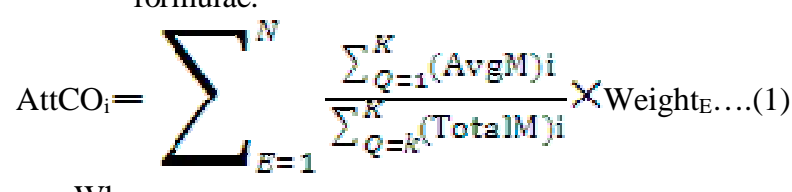

Where

$\mathrm{I}=$ Total number of Course Outcomes

$\mathrm{N}=$ Total number of exams conducted

$\mathrm{E}=$ Type of Exam (ESE, MSE, Quizzes, Problem solving contest)

$\operatorname{AvgM}(\mathrm{Q} 1 \text { to } \mathrm{k})_{\mathrm{i}}=$ Average Marks obtained by students in question 1 to $\mathrm{k}$

(Where questions 1 to $\mathrm{K}$ associated with $\mathrm{CO}_{\mathrm{i}}$ )

TotalM $(\mathrm{Q} 1 \text { to } \mathrm{k})_{\mathrm{i}}=$ Total Marks assigned to question 1 to $\mathrm{k}$

(Where questions 1 to $\mathrm{K}$ associated with $\mathrm{CO}_{\mathrm{i}}$ )

Step 4: To calculate attainment in percentage divide AvgM by TotalM and multiply it by 100 .

Hence we get value 54.6\%. Thus CO1 attainment for MSE is $54.6 \%$ for above sample example.

This same procedure has been applied for remaining exams to get $\mathrm{CO}$ attainment by direct method for data structure course. 


\section{CO Attainment Evaluation by Direct Method:}

Here we have considered data obtained in academic year 2014-15 to measure CO attainment of data structure course. Total 80 students marks in below mentioned assessment types have been considered to analyse $\mathrm{CO}$ Attainment. Table 3 shows the result obtained by applying above mentioned algorithm. The CO-Attainment-marks can be calculated as:

$\mathrm{ATT}_{\mathrm{CO}}=\operatorname{AvgMs}_{\mathrm{ESE}} \times 0.5+\operatorname{AvgM}_{\mathrm{MSE}} \times 0.3+\operatorname{AvgMOT} \times 0.10+\operatorname{AvgM}_{\mathrm{DT}} \times 0.10$ Where,

AvgM $_{\mathrm{OT}}=$ Average Marks obtained in Objective Test AvgM $\mathrm{DT}_{\mathrm{DT}}=$ Average Marks obtained in Debugging Test To evaluate the attainment of course learning outcome indirectly, it is essential that to take feedback from students in terms of course exit form filling activity[4]. The Questionary based on students course learning outcomes Table 3 : CO Attainment of data structure course in Academic

\begin{tabular}{|c|c|c|c|c|c|c|c|c|}
\hline \multicolumn{2}{|c|}{ Yea } & \multicolumn{2}{|c|}{ 2014-15 } & & & & & \\
\hline \multirow{2}{*}{\multicolumn{2}{|c|}{ Assessment }} & \multirow[t]{2}{*}{$\begin{array}{l}\text { Mar } \\
\text { ks }\end{array}$} & \multirow[t]{2}{*}{$\%$} & \multicolumn{5}{|c|}{$\begin{array}{c}\text { Course Outcome Attainment } \\
\text { (in \%) }\end{array}$} \\
\hline & & & & CO1 & $\mathrm{CO2}$ & $\mathrm{CO3}$ & $\mathrm{CO4}$ & $\mathrm{CO5}$ \\
\hline \multicolumn{2}{|l|}{ ESE } & 100 & 50 & 82.5 & 80.5 & 77.2 & 88.1 & 74.5 \\
\hline \multicolumn{2}{|c|}{ MSE } & 50 & 30 & 77.3 & 67.3 & 88 & 72.4 & 82.4 \\
\hline \multirow[t]{2}{*}{ ISE } & $\begin{array}{l}\text { Obj. } \\
\text { Test }\end{array}$ & 20 & 10 & 86.2 & 82.2 & 83.5 & 77.8 & 79.8 \\
\hline & $\begin{array}{l}\text { Debu } \\
\text { g Test }\end{array}$ & 20 & 10 & 88.1 & 83.4 & 87.2 & 72.5 & 70.3 \\
\hline \multicolumn{4}{|c|}{ Average } & 83.5 & $\begin{array}{c}78.3 \\
5\end{array}$ & 83.9 & 77.7 & 76.7 \\
\hline
\end{tabular}

\section{B] Indirct Method:}

The another method applied for measuring $\mathrm{CO}$ attainment do not considered the marks obtained by students directly from various examinations taking in particular academic year. Instead the feedback at the end of course have been taken from all registered students and below mentioned steps applied to evaluate $\mathrm{CO}$ attainment. Course Exit Surveys (CES) are an excellent means to obtain feedback from students. has been prepared and uploaded on local MOODLE server. All students who had registered for data structure course need to fill that course exit form. Table 4 shows some sample questions asked in course exit survey form.

\section{Algorithm2: CO Attainment Measurement through indirect approach}

Step1: Collect all information in subjective manner. Total 5 questions were asked in CES form which is corresponding to one of the $\mathrm{CO}$. Each question has 5 options and each option has some weight-age assigned. For example consider following questions along with corresponding course outcome.

Step2: To calculate CO attainment following formulae has been used:

$\mathrm{ATTCO}_{\mathrm{i}}=\Sigma_{W F T=1}^{W}$ ( Numofstudclick ${ }_{\mathrm{OPT}} \times$ Weight $\left._{\mathrm{OPT}}\right) . .(2)$

Where,

OPT $=$ options for each question

$\mathrm{i}=$ course outcomes 1 to 5

$\mathrm{N}=$ Total number of options

Numofstudclick $_{\mathrm{OPT}}=$ Number of students click on option OPT

Weight $_{\mathrm{OPT}}=$ Weightage assign to each OPT

Step3: To convert it into percentage apply following formulae

CO Attainment (in \%)=ATTCOi $* 100$

\begin{tabular}{|c|c|c|c|c|c|c|c|}
\hline \multicolumn{8}{|c|}{ Course Exit Survey Questionnaire } \\
\hline Que. No. & $\begin{array}{l}\text { Mapped } \\
\text { with } \\
\mathrm{CO}\end{array}$ & Question & \multicolumn{5}{|c|}{ Options } \\
\hline 1 & $\mathrm{CO} 1$ & $\begin{array}{l}\text { How many of following data structures, } \\
\text { advantages and applications you can able } \\
\text { to state? } \\
\text { Array, stack, queue, circular queue, linked } \\
\text { list, doubly linked list, circular linked list, } \\
\text { priority queue, de-queue, binary search } \\
\text { tree, B tree, AVL tree, heaps, graphs }\end{array}$ & $\begin{array}{l}\text { A] } \\
\text { All } 14\end{array}$ & $\begin{array}{l}\text { B] } \\
\text { Between } \\
9 \text { to } 13\end{array}$ & $\begin{array}{l}\text { C] } \\
\text { Between } \\
4 \text { to } 8\end{array}$ & $\begin{array}{l}\text { D] } \\
\text { Between } \\
1 \text { to } 3\end{array}$ & $\begin{array}{l}\text { E] } \\
\text { Zero }\end{array}$ \\
\hline 2 & $\mathrm{CO} 2$ & $\begin{array}{l}\text { How many of following data structures } \\
\text { you can able to implement in C? } \\
\text { Array, stack, queue, circular queue, linked }\end{array}$ & $\begin{array}{l}\text { A] } \\
\text { All } 14\end{array}$ & $\begin{array}{l}\text { B] } \\
\text { Between } \\
9 \text { to } 13\end{array}$ & $\begin{array}{l}\text { C] } \\
\text { Between } \\
4 \text { to } 8\end{array}$ & $\begin{array}{l}\text { D] } \\
\text { Between } \\
1 \text { to } 3\end{array}$ & $\begin{array}{l}\text { E] } \\
\text { Zero }\end{array}$ \\
\hline
\end{tabular}




\begin{tabular}{|l|l|l|l|l|l|l|}
\hline & $\begin{array}{l}\text { list, doubly linked list, circular linked list, } \\
\text { priority queue, de-queue, binary search } \\
\text { tree, B tree, AVL tree, heaps, graphs }\end{array}$ & & & \\
\hline
\end{tabular}

Table : CO Attainment of data structure course in Academic Year 2014-15 (by CES)

\begin{tabular}{|c|c|c|c|c|c|c|c|}
\hline \multirow{2}{*}{$\begin{array}{l}\text { Que } \\
\text { No }\end{array}$} & \multirow{2}{*}{$\begin{array}{l}\text { Mapped } \\
\text { With } \\
\text { CO }\end{array}$} & \multicolumn{5}{|c|}{ Course Exit Form Options } & \multirow{2}{*}{$\begin{array}{c}\mathrm{CO} \\
\text { Attainment } \\
\text { In } \%\end{array}$} \\
\hline & & $\begin{array}{c}\text { A } \\
\text { (Weight- } \\
\text { age 10) }\end{array}$ & $\begin{array}{c}\text { B } \\
\text { (Weight- } \\
\text { age } 8)\end{array}$ & $\begin{array}{c}\mathrm{C} \\
\text { (Weight-age } \\
6)\end{array}$ & $\begin{array}{c}\text { D } \\
\text { (Weight- } \\
\text { age 4) }\end{array}$ & $\begin{array}{c}\mathrm{E} \\
\text { (Weight-age } \\
0)\end{array}$ & \\
\hline & & \multicolumn{5}{|c|}{ Number of students Marked Options } & \\
\hline Q.1 & $\mathrm{CO} 1$ & 20 & 10 & 30 & 10 & 5 & 83.9 \\
\hline Q.2 & $\mathrm{CO} 2$ & 15 & 25 & 20 & 10 & 5 & 80.2 \\
\hline Q.3 & $\mathrm{CO} 3$ & 15 & 20 & 15 & 30 & 0 & 76.4 \\
\hline Q.4 & $\mathrm{CO} 4$ & 12 & 28 & 16 & 24 & 2 & 78.3 \\
\hline Q.5 & $\mathrm{CO5}$ & 10 & 20 & 20 & 20 & 5 & 67.5 \\
\hline
\end{tabular}

\section{CO Attainment Evaluation by Indirect Method:}

Algorithm 2 has been applied to calculate $\mathrm{CO}$ attainment of data structure course in academic year 2014-15 which results in below table.

For example to calculate CO1 attainment, Apply Formulae2,

$$
\begin{aligned}
\text { ATTCO } 1 & =(20 / 75) * 10+(10 / 75) * 8+(30 / 75) * 6+(10 / 75) * 4 \\
& +(5 / 75) * 0
\end{aligned}
$$$$
=0.839
$$

Now apply formulae(3) to get attainment in percentage, $\mathrm{CO}$ Attainment $($ in $\%)=0.839 * 100$

$$
=83.9 \%
$$

\section{RESULT ANALYSIS}

The overall attainment is calculated by considering the separate weight age to each method. i.e. $80 \%$ and $20 \%$ weight-ages are given to direct and indirect methods respectively.

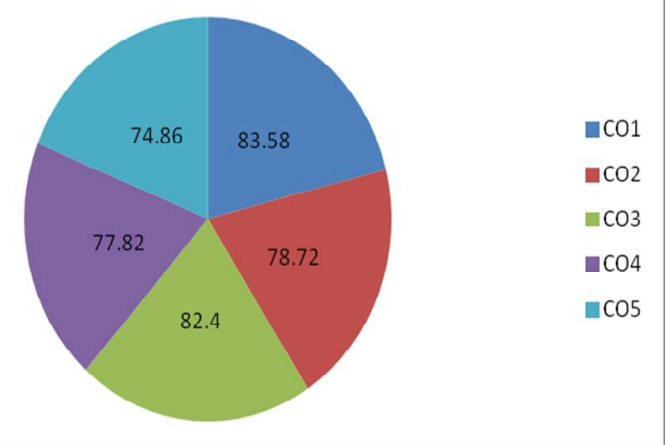

From above diagram it is observed that the attainment for data structure course for course outcomes 1 to 5 has been satisfying the minimum criteria. It is observed that the students are good in understanding the basic concepts of course as CO:1 attainment is scored the highest percentage.
$\mathrm{CO}: 2$ has been attained 78.72 percent, hence we can conclude that around $78 \%$ students programming skill is good while CO:3 is also scored good percentage i.e. 82.4, which reflects the students understanding in non linear data structures. $\mathrm{CO}: 4$ is attained by $77.8 \%$, hence hash functioning concepts are also clear up to some extent. Even minimum threshold value is achieved by CO:5 i.e. 74.86 , though the students are lagging in mapping the applications of data structure with real life problems up to some extent. This problem can be solved by giving more real life problems during teaching the course.

Table : Result of CO Attainment

\begin{tabular}{|l|l|l|l|l|l|}
\hline \multicolumn{7}{|c|}{ Course Outcomes } \\
\hline & CO1 & CO2 & CO3 & CO4 & CO5 \\
\hline $\begin{array}{c}\text { Attainment } \\
\text { level of CO } \\
\text { (in \%) }\end{array}$ & 83.58 & 78.72 & 82.4 & 77.82 & $\begin{array}{l}74.86 \\
\text { (rounded } \\
\text { to 75) }\end{array}$ \\
\hline $\begin{array}{l}\text { Threshold } \\
\text { value }\end{array}$ & 75 & 75 & 75 & 75 & 75 \\
\hline Deviation & +8.58 & +3.72 & +7.4 & +2.82 & -0.24 \\
\hline $\begin{array}{l}\text { Achievement } \\
\text { Goal: 75\%) }\end{array}$ & YES & YES & YES & YES & YES \\
\hline
\end{tabular}

\section{CONCLUDING REMARKS}

In this paper we presented direct and indirect methods to solve the $\mathrm{CO}$ attainment of data structure course. The result obtained in academic year 2014-15 has been analysed. The overall $\mathrm{CO}$ attainment is obtained by both direct and indirect methods, whereas different weight- ages have been considered for each methodology i.e. $80 \%$ for direct and $20 \%$ for indirect approach. It is observed that all five course outcomes have been satisfied the minimum requirement of $75 \%$. As course outcome $\mathrm{CO} 5$, has attained with negative deviation of -0.24 , it is necessary to work on application oriented approach. The students are good in understanding the basic terminologies as $\mathrm{CO} 1$ and $\mathrm{CO} 3$ attained with 83.58 and 82.4 percentages respectively. The programming skills are satisfactory $(\mathrm{CO} 2: 78.72 \%)$, but 
need to improve by applying innovative teaching methodologies. It is decided to strengthen the threshold value of $\mathrm{CO}$ attainment up to $80 \%$ in next academic year 2015-16.

\section{REFERENCES}

[1] National Board of Accreditation Manual for Diploma Engineering Programmes (Tier-II), January 2013.

[2] Zamri Mohamed, Mohd Yusof Taib, M.S. Reza, "Assessment Method Based for Course Outcome and Program Outcome in Outcome Education (OBE)", Malaysian Technical Universities Conference on Engineering and Technology, June 28-29, 2010.

[3] National Board of Accreditation: Orientation Workshop On

Outcome Based Accreditation, New Delhi 110003, 2010 .

[4] Izham Zainal Abidin,, Adzly Anuar and Norshah Hafeez Shuaib, "Assessing the attainment of course outcomes (CO) for an engineering course", in International Conference of Teaching and Learning (ICTL 2009) INTI University College, Malaysia. 